\title{
KAJIAN KAPASITAS RUMAH TANGGA TERHADAP BENCANA KABUT ASAP DI KELURAHAN BANSIR DARAT, KOTA PONTIANAK
}

(The Study Of Household Capacity Against Smoke Haze Disaster in

Kelurahan Bansir Darat, Pontianak City)

\section{Aji Rio Sutrisno ${ }^{1,2}$, Djoko Santoso Abi Suroso ${ }^{1}$}

\begin{abstract}
Abstrak : Kebakaran hutan dan lahan (karhutla) di Indonesia menimbulkan degradasi lingkungan, kerugian ekonomi dan gangguan kesehatan. Fenomena Strong El Nino menjadi faktor alam yang memperparah kondisi karhutla, upaya pengurangan risiko karhutla dengan mencegah, mengurangi dan menanggulangi karhutla terus diupayakan pemerintah. Kabut asap karhutla menjadi masalah tersendiri, luasnya wilayah terpapar dan partikel berbahaya mengganggu aktivitas masyarakat terutama gangguan kesehatan. Upaya pengurangan risiko bencana dapat dilakukan dengan meningkatkan kapasitas, adapun salah satu jenis kapasitas yang ada di masyarakat adalah kapasitas rumah tangga. Tujuan dari studi ini adalah melakukan kajian kapasitas rumah tangga dalam menghadapi bencana kabut asap karhutla, lokasi yang dipilih untuk melakukan studi adalah Kelurahan Bansir Darat, Kota Pontianak-Kalimantan Barat. Pembahasan dimulai dengan menentukan kriteria kapasitas rumah tangga, teknik pengambilan sampel data adalah non probability sampling berupa pengambilan sampel sistematis melalui angket berjumlah 110 dan metode analisis data dilakukan secara kuantitatif deskriptif dan kuantitatif asosiasi. Karakteristik rumah tangga yang teridentifikasi adalah kelompok umur, kelompok pekerjaan dan jenis permukiman, perhitungan kapasitas rumah tangga menunjukkan bahwa $21,82 \%$ siap, $28,18 \%$ tidak siap dan $50,00 \%$ cukup siap menghadapi bencana, ditemukan hubungan yang signifikan antara kelompok pekerjaan dengan kapasitas rumah tangga dan jenis permukiman dengan kapasitas rumah tangga.
\end{abstract}

\section{Kata kunci : Kapasitas rumah tangga, kabut asap, karhutla, bansir darat, pontianak}

Absract : Forest and land fires (karhutla) in Indonesia cause environmental degradation, economic losses and health problems. The phenomenon of Strong El Nino becomes a natural factor that exacerbates the condition of karhutla, efforts to reduce the risk of karhutla by preventing, reducing and tackling the karhutla continue to be pursued by the government. The haze of karhutla becomes a problem in itself, the extent of exposed areas and dangerous particles disrupt the activities of the community, especially health problems. Disaster risk reduction efforts can be done by increasing capacity, while one type of capacity in the community is household capacity. The purpose of this study is to review the capacity of households in the face of smoke haze karhutla, the location chosen to conduct the study is Kelurahan Bansir Darat, Pontianak City-West Kalimantan. The discussion begins with determining the criteria of household capacity, the data sampling technique is non

\footnotetext{
${ }^{1}$ Sekolah Arsitektur, Perencanaan dan Pengembangan Kebijakan - Institut Teknologi Bandung

${ }^{2}$ Pusbindiklatren BAPPENAS (Karyasiswa Diklat Gelar)
} 
probability sampling in the form of systematic sampling through questionnaire amounting to 110 and the method of data analysis is done quantitatively descriptive and quantitative associations. Identified household characteristics were age group, occupation group and settlement type, household capacity calculation showed that $21.82 \%$ were ready, $28.18 \%$ were not ready and $50.00 \%$ were adequately prepared for the disaster, found significant relationship between work groups with household capacity and type of settlement with household capacity.

Keyword : Household capacity, smoke haze, forest and land fire, bansir darat, pontianak

\section{PENDAHULUAN}

Kebakaran hutan dan lahan (karhutla) yang terjadi di wilayah Indonesia telah menimbulkan kerugian ekonomi yang mencakup kerusakan sumberdaya air, emisi karbon, kerusakan tanaman dan pohon, kerusakan keanekaragaman hayati, biaya kesehatan, kerugian perdagangan, pariwisata dan biaya-biaya restorasi ekosistem (Purnomo et al., 2017). Karhutla di Indonesia dan di kawasan asia tenggara sangat dipengaruhi oleh iklim, Chandler et al (1983) dalam Syaufina (2008) menyatakan bahwa cuaca dan iklim mempengaruhi kebakaran hutan dan lahan dengan berbagai cara yang saling berhubungan sebagai berikut :

1. Iklim menentukan jumlah total bahan bakar yang tersedia.

2. Iklim menentukan jangka waktu dan keparahan musim bakaran.

3. Cuaca mengatur kadar air dan kemudahan bahan bakar hutan untuk terbakar.

4. Cuaca memengaruhi proses penyalaan dan penjalaran kebakaran hutan.

Fenomena Strong El Nino sering disebut sebagai faktor yang memperparah karhutla (Heil \& Goldammer, 2001). Strong El Nino mengakibatkan musim hujan yang tertunda sehingga karhutla terjadi lebih lama dibanding biasanya, lahan kering akibat kemarau yang lebih panjang mengakibatkan api dengan mudah menyebar dan bahkan meluas hingga menimbulkan kebakaran di dalam lahan gambut (Frankenberg et al., 2004). Ada beberapa karhutla besar di Indonesia yang dipengaruhi Strong El Nino terjadi dalam 40 tahun terakhir tiga diantaranya terjadi pada tahun 1982/1983, 1997/1998 dan yang terakhir terjadi tahun 2015 (Hendon, 2003; Tacconi, 2003; Stockwell et al., 2016), adapun Moderate El Nino terjadi di tahun 2006 (Logan et al., 2008).

Menurut Tacconi (2003) berbagai studi mengenai kebakaran hutan yang sudah dilakukan di Indonesia belum banyak memberikan manfaat dalam mengatasi akar permasalahan, dengan alasan adanya kerancuan kebijakan, keterbatasan pemahaman tentang dampaknya terhadap ekosistem, dan kekaburan tentang berbagai penyebab kebakaran hutan sebagai akibat ketidakpastian tanggapan secara ekonomi dan kelembagaan terhadap kebakaran hutan. Kejadian karhutla secara umum masih sulit untuk dikurangi karena keuntungan dan permintaan pasar yang tinggi terhadap kelapa sawit telah memberikan insentif dalam penggunaan api yang murah untuk membuka lahan sehingga kebakaran dan kabut asap akan terus terjadi setiap tahunnya (Purnomo et al., 2017).

Kabut asap yang dihasilkan karhutla menjangkau wilayah yang jauh lebih luas dari hutan dan lahan yang terbakar bahkan tidak hanya melewati wilayah administrasi kabupaten/kota atau provinsi tetapi sampai ke negara tetangga, kejadian karhutla besar dan menghasilkan kabut asap yang melewati batas negara sampai ke Singapura dan Malaysia dalam 5 tahun terakhir terjadi pada 2013, 2014, 2015 (BNPB, 2015).

Komponen asap akibat kebakaran hutan dan lahan dapat memiliki sifat fisik dan kimia yang berbeda karena terbentuk oleh pembakaran tidak sempurna, tergantung pada asal usulnya yang dapat berkorelasi dengan dampak kesehatan pada populasi yang terpapar, dimana bentuk partikel (bulat, tidak beraturan, berserat) bergantung pada suhu pembakaran dan juga mempengaruhi kemampuan penetrasi partikel (Statheropoulos \& Karma, 2007). Asap menurut Girard (1992) dalam Purnomo et al. (2015) adalah suspensi pertikel-partikel 
padat dan cair dalam medium gas, kabut asap akibat karhutla sangat beracun (toxic smoke) karena mengandung partikel karbon monoksida (CO), nitrogen dioksida $\left(\mathrm{NO}_{2}\right)$, sulfur dioksida $\left(\mathrm{SO}_{2}\right)$ dan Ozon $\left(\mathrm{O}_{3}\right)$ yang berbahaya bagi kesehatan. Hasil dari tinjauan studi yang telah dilakukan menunjukkan bahwa kabut asap akibat kebakaran hutan secara konsisten dikaitkan dengan gangguan pernafasan (Liu, Pereira, Uhl, Bravo, \& Bell, 2015), di Indonesia kabut asap mengakibatkan beberapa jenis penyakit yaitu: infeksi saluran pernafasan akut (ISPA), asma bronkial, pneumonia, iritasi mata, iritasi kulit, dan diare (KMNLH RI, 1998; Tangang et al., 2010).

Pencegahan dan pengurangan risiko kejadian karhutla masih terus diupayakan oleh pemerintah baik koordinasi oleh BNPB di pemerintah pusat maupun koordinasi oleh BPBD di pemerintah daerah. Selama proses pengurangan risiko kejadian karhutla berlangsung, ancaman bencana karhutla dan kabut asap masih cukup tinggi terutama di tahun terjadinya fenomena El Nino. Untuk itu, dalam upaya mengurangi risiko bencana kabut asap yang diakibatkan karhutla tidak cukup dengan mencegah dan menanggulangi kejadian karhutla sebagai sumber ancaman tetapi diperlukan peningkatan kapasitas dalam menghadapi paparan kabut asap yang sangat berbahaya dan menjangkau wilayah yang sangat luas.

Menurut Hansford (2011) kapasitas adalah kemampuan untuk mempersiapkan, merespons dan pulih dari dampak bahaya, mengurangi kerusakan dan kerugian, dimana kapasitas memiliki kemiripan dengan kerentanan dan bisa sangat bervariasi dari satu negara ke negara lain, dari satu tempat ke tempat lain dan dari satu keluarga ke keluarga lain. Sedangkan dalam Perka BNPB No. 2 Tahun 2012 yang dimaksud dengan kapasitas adalah kemampuan daerah dan masyarakat untuk melakukan tindakan pengurangan ancaman dan potensi kerugian akibat bencana. Dari dua definisi diatas maka pengurangan risiko bencana karhutla dan kabut asap tidak hanya ditentukan oleh peran pemerintah tetapi perlu dukungan kesiapan dari masyarakat dalam menghadapi bencana, masyarakat sebagai obyek yang terdampak dituntut untuk mampu bertahan dalam mengantisipasi bencana dengan kemampuan yang dimiliki.

Dengan tingkat ancaman karhutla penyebab kabut asap yang cukup tinggi, wilayah dari paparan kabut asap yang luas, dan bahaya kesehatan yang ditimbulkan partikel kabut asap karhutla, maka diperlukan kajian mengenai kapasitas dalam menghadapi bencana kabut asap dari karhutla. Adapun yang menjadi obyek kajian kapasitas dalam penelitian ini adalah kapasitas rumah tangga, sehingga dapat memberikan gambaran bagi pemerintan (pusat dan daerah) dalam upaya meningkatkan kapasitas untuk menghadapi bencana kabut asap dari karhutla berupa karakteristik rumah tangga, tingkat kapasitas rumah tangga dan hubungan antara karakteristik dan kapasitas rumah tangga.

Penelitian ini dilakukan di Kelurahan Bansir Darat di Kota Pontianak, Kota Pontianak merupakan ibu kota Kalimantan Barat yang termasuk dalam 6 provinsi dengan kasus karhutla terparah sehingga mengalami paparan kabut asap hampir setiap tahun karena dikelilingi wilayah dengan titik api yang cukup tinggi. Adapun pemilihan Kelurahan Bansir Darat karena keunikan karakteristik wilayah administrasinya dimana Kelurahan Bansir Darat termasuk dalam 3 kelurahan yang ditetapkan sebagai rawan karhutla di Kota Pontianak tetapi dikembangkan juga sebagai kawasan pusat perkantoran.

Sebelum melakukan kajian kapasitas rumah tangga dalam menghadapi bencana kabut asap dari karhutla perlu ditentukan terlebih dahulu kriteria pembentuk kapasitas rumah tangga, pembahasan dalam menentukan kriteria kapasitas rumah tangga dalam menghadapi bencana kabut asap dari karhutla akan dijelaskan pada bagian tersendiri. 


\section{Kriteria Kapasitas Rumah Tangga}

Menurut UNISDR (2009) kapasitas adalah kombinasi semua kekuatan, atribut dan sumber daya yang tersedia dalam masyarakat yang dapat digunakan untuk mencapai suatu tujuan yang mencakup infrastruktur dan sarana fisik, lembaga, kemampuan masyarakat, serta pengetahuan manusia, keterampilan dan atribut kolektif seperti hubungan sosial, kepemimpinan dan manajemen. Penelitian-penelitian untuk mengukur kapasitas rumha tangga telah banyak dilakukan khususnya mengenai kapasitas adaptif dalam menghadapi dampak perubahan iklim. Dalam studi ini kriteria yang digunakan untuk mengukur kapasitas rumah tangga dalam menghadapi bencana kabut asap dari karhutla adalah sebagai berikut:

\section{Ekonomi}

Burton et al. (1998) dan Kates (2000) dalam Smit \& Piliposova (2003) menyatakan bahwa aset ekonomi, sumber daya modal, sarana keuangan, kekayaan, atau kemiskinan, kondisi ekonomi jelas merupakan penentu kapasitas, sedangkan menurut Wall \& Marzall (2006) penduduk dengan pekerjaan tetap (aman) dapat berinvestasi dalam strategi pencegahan dan adaptasi dan bertahan menghadapi kesulitan keuangan daripada mereka yang tidak memiliki pekerjaan tetap. Penalba dan Elazegui (2011) menggunakan kepemilikan tanah, kendaraan, dan pendapatan sebagai indikator ekonomi kapasitas rumah tangga, secara umum dapat dikatakan bahwa kondisi ekonomi yang lebih baik akan meningkatkan kapasitas rumah tangga.

\section{Pengetahuan dan Keterampilan}

Menurut Smit \& Piliposova (2003) keterampilan yang terlatih meningkatkan tingkat kapasitas, sedangkan Wall \& Marzall (2006) mendefinisikan sumber daya manusia sebagai keterampilan, pendidikan, pengalaman, dan kemampuan umum dari individu yang dikombinasikan dengan ketersediaan individu produktif. Adapun Ross (2013) menggunakan istilah kapasitas sosial yang didefinisikan sebagai gabungan karakteristik masyarakat termasuk usia, tingkat pendidikan, kekayaan, kemampuan bahasa untuk menterjemahkan, keleluasaan, dan memiliki sumber daya jika terjadi bencana. Dari beberapa pendapat diatas maka kriteria pengetahuan dan keterampilan dari rumah tangga dapat memberikan alternatif tindakan untuk menghadapi bencana.

\section{Teknologi dan Informasi}

Smit et al. (2001) dalam Swanson (2007) menekankan bahwa kurangnya penggunaan teknologi membatasi jangkauan pilihan potensi adaptasi, dimana daerah yang kurang menerapkan teknologi cenderung untuk tidak mengembangkan dan/atau menerapkan adaptasi teknologi dan akses informasi yang baik meningkatkan kemungkinan adaptasi tepat waktu dan tepat sasaran. Oleh karena itu pemanfaatan dan ketersediaan teknologi dan informasi oleh rumah tangga mempercepat tindakan antisipasi ketika terjadi bencana.

\section{Infrastruktur}

Ross (2013) mendefinisikan kapasitas infrastruktur sebagai layanan publik masyarakat dasar dalam hal tempat tinggal, jalan, dan fasilitas medis yang mungkin diperlukan jika terjadi bencana, sedangkan menurut Swanson (2007) karakteristik dan lokasi infrastruktur dapat mempengaruhi kapasitas adaptif. Untuk itu pemanfaatan dan ketersediaan infrastruktur yang baik menjamin pelayanan dasar sehingga meningkatkan kapasitas rumah tangga.

Untuk lebih jelasnya sintesa penentuan kriteria kapasitas rumah tangga dalam menghadapi bencana kabut asap dari karhutla dapat dapat dilihat pada Tabel 2. Berdasarkan 
kriteria kapasitas rumah tangga yang telah ditentukan, maka variabel yang digunakan sebagai indikator dalam penelitian ini adalah sebagai berikut:

Tabel 1. Indikator kapasitas rumah tangga dalam menghadapi bencana kabut asap

\begin{tabular}{ll}
\hline \multicolumn{1}{c}{ Kriteria } & \multicolumn{1}{c}{ Indikator } \\
\hline \multirow{4}{*}{ Ekonomi } & - Pendapatan \\
& - Pekerja Selain KK \\
& - Aset Kendaraan Pribadi \\
& - Jaminan Kesehatan \\
& - Daya Beli Air Konsumsi \\
& - Pengalaman Bencana \\
& - Pendidikan \\
& - Pelatihan Kebencanaan \\
Pengetahuan dan Keterampilan & - Tindakan Antisipasi Bencana \\
& - Persediaan Obat-obatan \\
& - Media Akses Peringatan Dini \\
& - Jumlah Pengguna Internet \\
& - Akses Informasi Kondisi Udara \\
& - Akses Udara Bersih \\
Teknologi dan Informasi & - Teknologi Pembersih Udara \\
& - Pemanfaatan AQMS \\
& - Kondisi AQMS \\
& - Jarak Puskesmas \\
& - Kondisi Akses Jalan Puskesmas \\
& - Alternatif Fasilitas Kesehatan \\
\hline
\end{tabular}

\section{METODE}

Data yang digunakan dalam penelitian ini adalah data primer melalui angket yang disebar kepada sampel rumah tangga yang ada di Kelurahan Bansir Darat. Jumlah penduduk yang ada di Kelurahan Bansir Darat sebanyak 8.632 jiwa yang terdiri dari 2.091 kepala keluarga (Profil Kecamatan Pontianak Tenggara, 2016), dengan taraf signifikasi sebesar 0,1 maka jumlah sampel minimal yang diperlukan adalah 95,44 yang kemudian dibulatkan dan ditambah menjadi 110 sampel.

Teknik yang digunakan dalam pengambilan sampel dalam penelitian ini adalah non probability sampling berupa pengambilan sampel sistematis dimana sampel yang dipilih dalam populasi dipisahkan berdasarkan interval tertentu. Interval pengambilan sampel ditentukan dengan membagi populasi dengan jumlah sampel, populasi sejumlah 2.091 kemudian dibagi sampel sejumlah 110 didapatkan 19,01 yang dibulatkan menjadi 19 . Dengan interval sampel 19 dan sampel pertama adalah rumah tangga ke 1 maka sampel rumah tangga pada Kelurahan Bansir Darat diambil dengan urutan sebagai berikut: 1, 20, 39, $58,77,96,115,134, \ldots \ldots, 2072$, dengan asumsi dalam satu rumah memiliki setidaknya satu rumah tangga. Pengambilan sampel sistematis di Kelurahan Bansir Darat dilakukan dengan menyusuri jalan-jalan yang ada yaitu : jalan Perdana, jalan Reformasi, jalan Sepakat II, jalan Padat Karya, jalan Karya dan jalan Parit Haji Husin II, sedangkan jalan Ahmad Yani yang merupakan kawasan perkantoran tidak diambil sampelnya. Penentuan rumah pertama dilakukan di jalan Perdana kemudian penomoran rumah berdasarkan interval yang telah ditentukan dilakukan secara manual, untuk rumah yang terpilih sebagai sampel tetapi tidak ada penghuninya maka akan dialihkan ke rumah disebelahnya sampai didapatkan sampel setelah itu perhitungan sampel dilanjutkan kembali sesuai dengan interval yang telah ditetapkan. 
Kajian Kapasitas Rumah Tangga terhadap Bencana Kabut

Asap

255

Tabel 2. Sintesa kriteria kapasitas rumah tangga dalam menghadapi bencana kabut asap

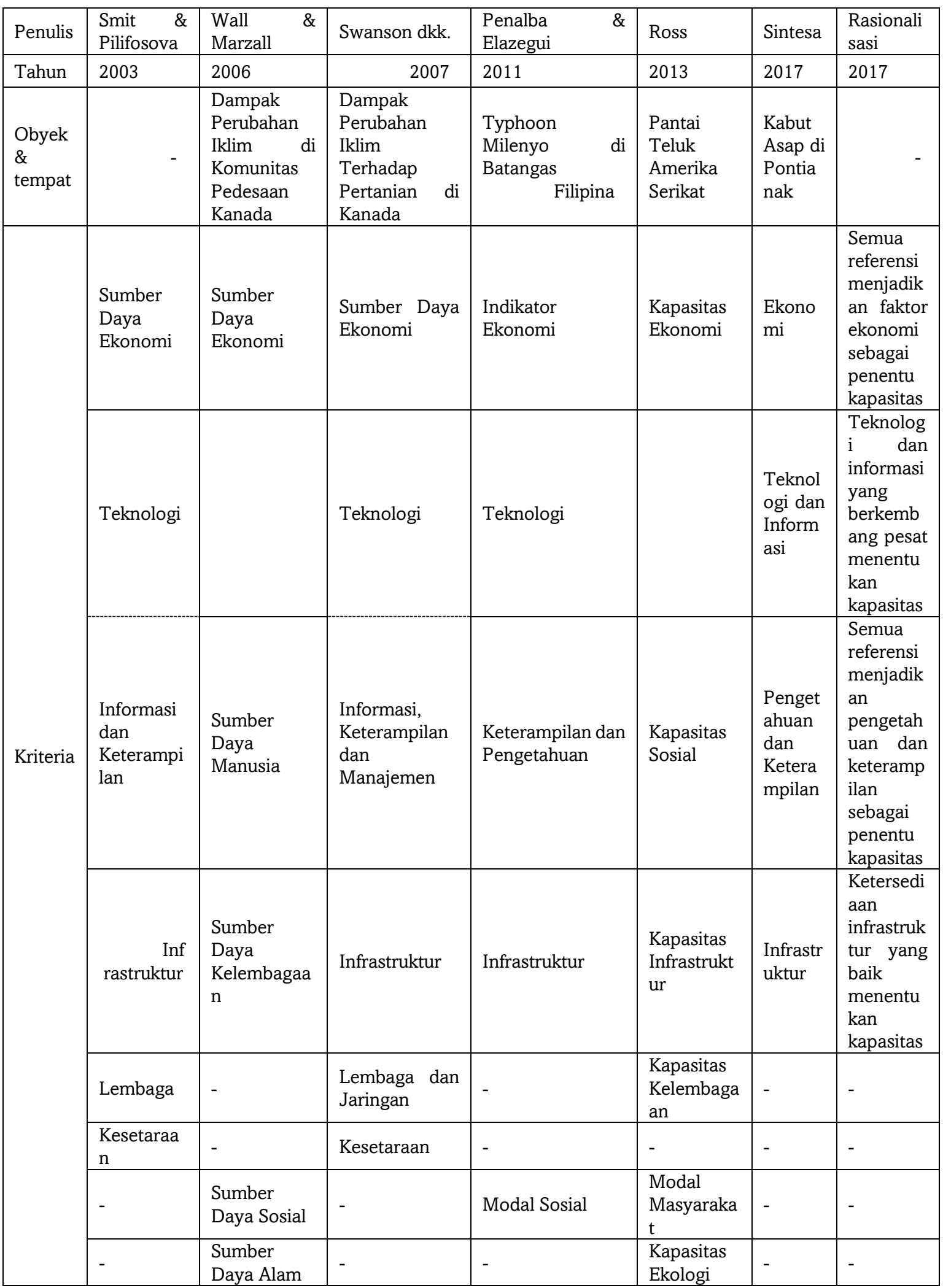


Analisis data untuk mengidentifikasi karakteristik rumah tangga dan kapasitas rumah tangga dalam menghadapi bencana kabut asap dari karhutla dilakukan secara kuantitatif deskriptif, sedangkan untuk mengetahui hubungan antara karakteristik rumah tangga dan kapasitas rumah tangga dilakukan analisis kuantitatif asosiasi menggunakan Independent Sample T Test.

\section{HASIL DAN DISKUSI}

Hasil

\section{Karakteristik Responden Rumah Tangga}

Komposisi jenis kelamin kepala keluarga atau yang mewakili dari responden di Kelurahan Bansir Darat adalah sebagai berikut:

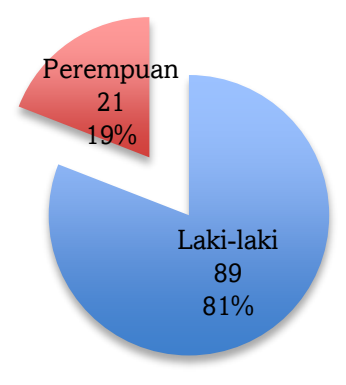

\section{Gambar 1. Komposisi responden berdasarkan jenis kelamin}

Dari tabel diatas dapat dilihat bahwa dari 110 reponden mayoritas kepala keluarga atau yang mewakili menjadi responden adalah laki-laki dengan jumlah 89 orang atau sekitar $81 \%$ sedangkan sisanya adalah perempuan dengan jumlah 21 orang atau sekitar $19 \%$.

Komposisi rentang usia kepala keluarga atau yang mewakili dari responden di Kelurahan Bansir Darat adalah sebagai berikut:

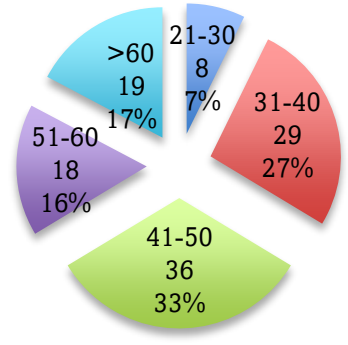

Gambar 2. Komposisi responden berdasarkan usia

Gambar diatas menunjukkan bahwa sebagian besar usia responden ada di rentang 2140 tahun dan 41-50 tahun yaitu berjumlah 65 orang atau sekitar $65 \%$ dari 110 orang responden, hal ini mengindikasikan sebagian besar responden berada dalam usia produktif. 
Komposisi kelompok pekerjaan kepala keluarga atau yang mewakili dari responden di Kelurahan Bansir Darat adalah sebagai berikut:

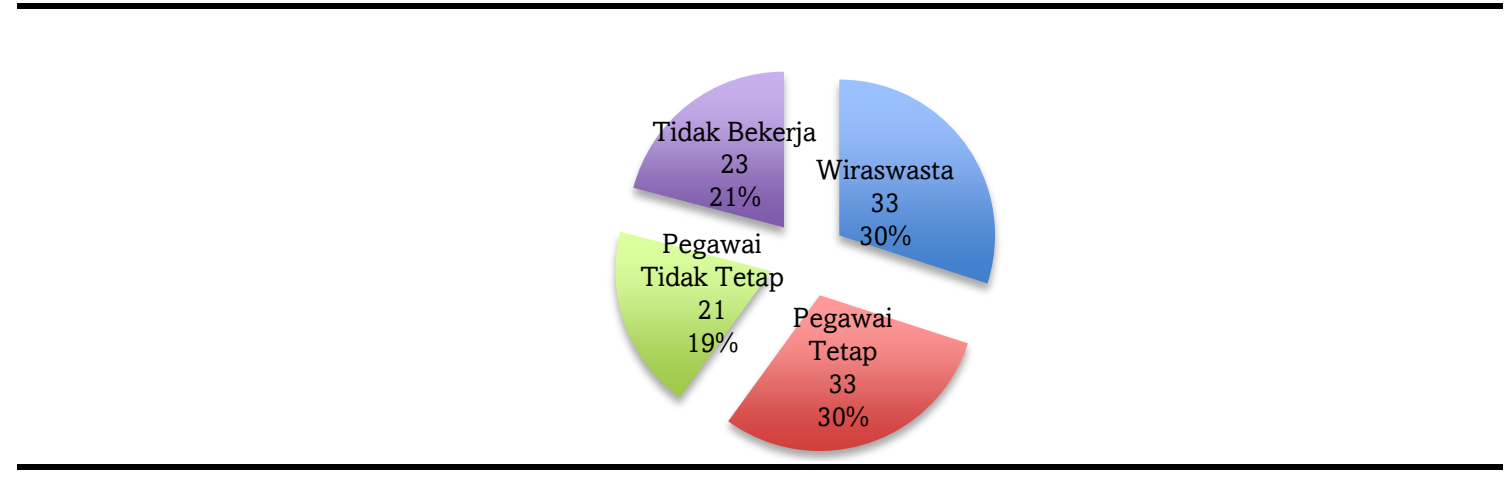

\section{Gambar 3. Komposisi responden berdasarkan kelompok pekerjaannya}

Dari gambar diatas dapat dilihat jumlah responden yang tidak bekerja berjumlah 23 orang atau $21 \%$ dari seluruh responden, jika dilihat dari komposisi usia responden terlihat bahwa sebanyak 19 orang berusia diatas 60 tahun atau tidak dalam usia produktif dan dapat diasumsikan telah memasuki masa pensiun.

Komposisi jenis permukiman yang dihuni rumah tangga dari responden di Kelurahan Bansir Darat adalah sebagai berikut:

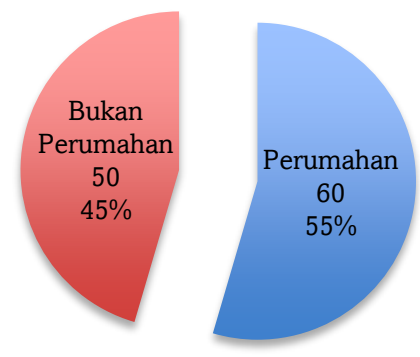

\section{Gambar 4. Komposisi responden berdasarkan jenis permukiman}

Dari gambar diatas dapat dilihat jumlah responden yang bertempat tinggal di perumahan adalah 60 rumah tangga atau $54,55 \%$ sedangkan sisanya yaitu sebesar $45,45 \%$ bertempat tinggal di permukiman yang dibangun sendiri atau bukan perumahan.

\section{Kapasitas Rumah Tangga}

Sebelum melakukan analisis terhadap kapasitas rumah tangga di Kelurahan Bansir Darat dalam menghadapi bencana kabut asap dari karhutla, terlebih dahulu akan dilakukan analisis berdasarkan kriteria kapasitas rumah tangga yang telah ditentukan sebelumnya. Adapun hasil analisis kapasitas rumah tangga di Kelurahan Bansir Darat adalah sebagai berikut: 


\section{Kriteria Ekonomi}

Hasil perhitungan skor terhadap indikator-indikator untuk kriteria ekonomi rumah tangga di Kelurahan Bansir Darat dalam menghadapi kabut asap ditunjukkan oleh gambar sebagai berikut:

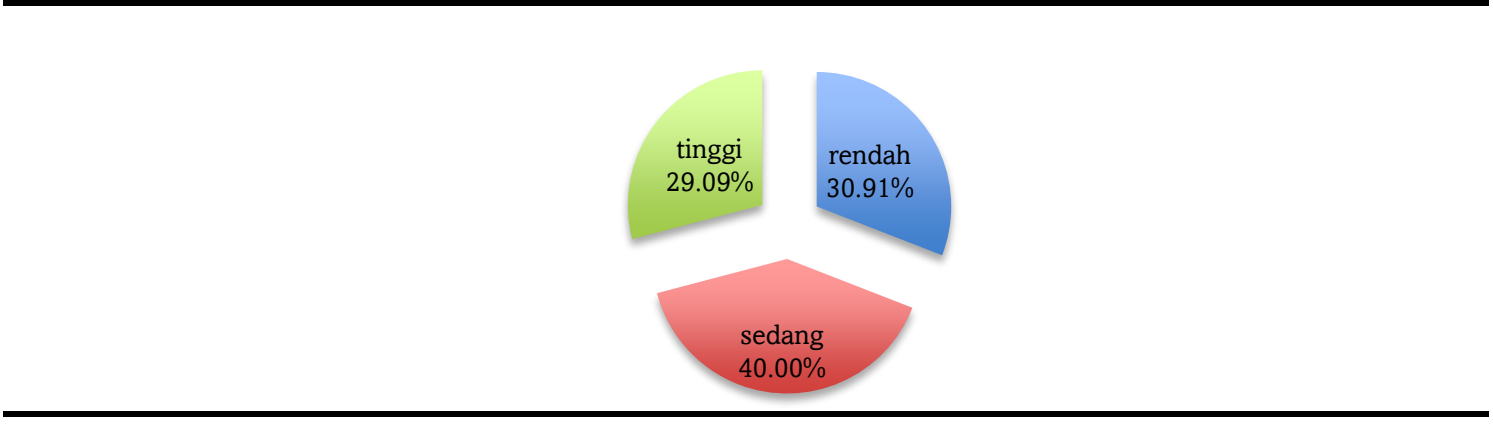

Gambar 5. Tingkat ekonomi rumah tangga di Kelurahan Bansir Darat

Dari gambar dapat dilihat bahwa tingkat kriteria ekonomi rumah tangga di Kelurahan Bansir Darat sebesar 29,09\% berada pada tingkat tinggi, 30,91\% berada pada tingkat rendah, dan porsi tertinggi yaitu sebesar $40,00 \%$ berada pada tingkat sedang.

\section{Kriteria Pengetahuan dan Keterampilan}

Hasil perhitungan skor terhadap indikator-indikator untuk kriteria pengetahuan dan keterampilan rumah tangga di Kelurahan Bansir Darat dalam menghadapi kabut asap ditunjukkan oleh gambar sebagai berikut:

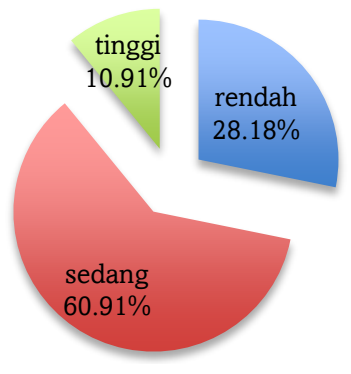

\section{Gambar 6. Tingkat pengetahuan dan keterampilan rumah tangga di Kelurahan Bansir Darat}

Dari gambar dapat dilihat bahwa tingkat kriteria pengetahuan dan keterampilan rumah tangga di Kelurahan Bansir Darat sebesar 10,91\% berada pada tingkat tinggi, 28,18\% berada pada tingkat rendah, dan mayoritas yaitu sebesar $60,91 \%$ berada pada tingkat sedang.

\section{Kriteria Teknologi dan Informasi}

Hasil perhitungan skor terhadap indikator-indikator untuk kriteria teknologi dan informasi rumah tangga di Kelurahan Bansir Darat dalam menghadapi kabut asap ditunjukkan oleh gambar sebagai berikut: 


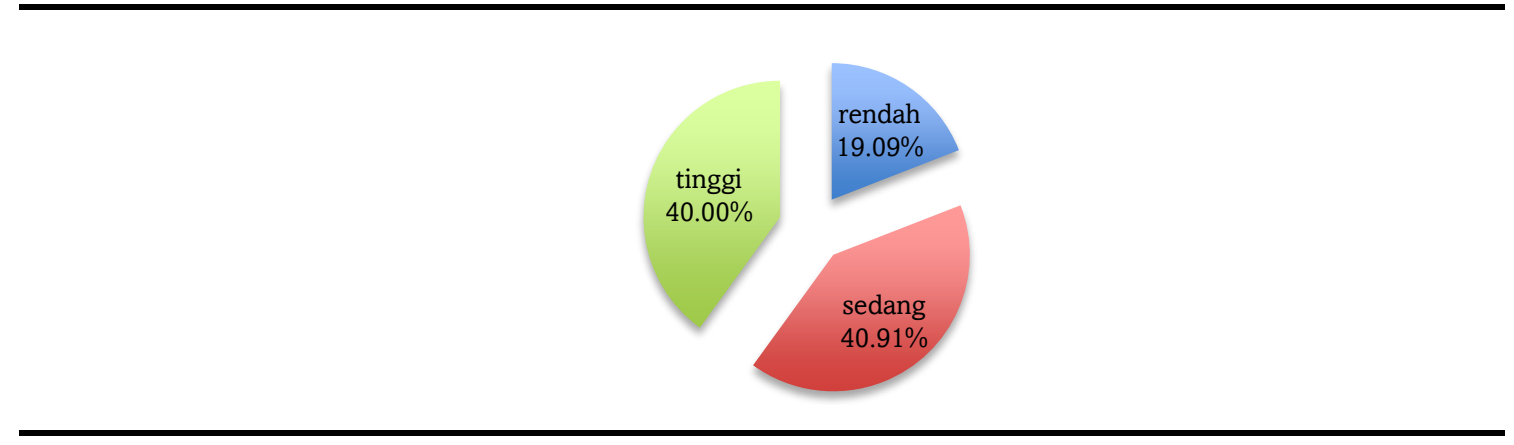

Gambar 7. Tingkat kriteria teknologi dan informasi rumah tangga di Kelurahan Bansir Darat

Dari gambar dapat dilihat bahwa tingkat kriteria teknologi dan informasi rumah tangga di Kelurahan Bansir Darat sebesar 40,00\% berada pada tingkat tinggi, 19,09\% berada pada tingkat rendah, dan sisanya yaitu sebesar $40,91 \%$ berada pada tingkat sedang.

\section{Kriteria Infrastruktur}

Hasil perhitungan skor terhadap indikator-indikator untuk kriteria infrastruktur rumah tangga di Kelurahan Bansir Darat dalam menghadapi kabut asap ditunjukkan oleh gambar sebagai berikut:

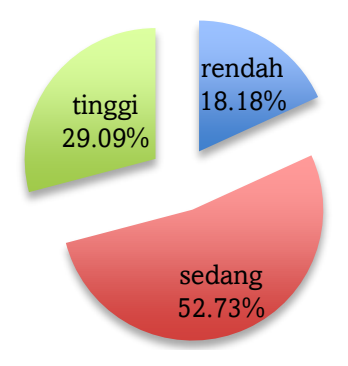

\section{Gambar 8. Tingkat infrastruktur rumah tangga di Kelurahan Bansir Darat}

Dari gambar dapat dilihat bahwa tingkat kriteria infrastruktur rumah tangga di Kelurahan Bansir Darat sebesar 29,09\% berada pada tingkat tinggi, 18,18\% berada pada tingkat rendah, dan sisanya yaitu sebesar $52,73 \%$ berada pada tingkat sedang.

\section{Tingkat Kapasitas Rumah Tangga}

Berdasarkan perhitungan semua skor indikator dari kriteria yang telah ditentukan untuk mengukur kapasitas rumah tangga di Kelurahan Bansir Darat dalam menghadapi bencana kabut adap dari karhutla, tingkat kapasitas rumah tangga yang dihasilkan dapat dilihat pada gambar berikut ini: 


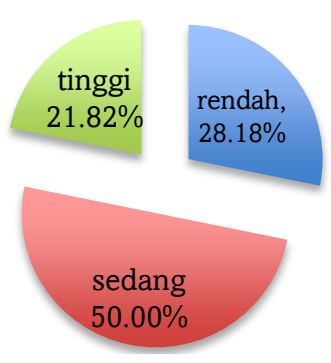

Gambar 9. Tingkat kapasitas rumah tangga di Kelurahan Bansir Darat

Secara umum tingkat kapasitas rumah tangga di Kelurahan Bansir Darat dalam menghadapi bencana kabut asap berada pada tingkat sedang dengan porsi 50,00\%, sedangan $21,82 \%$ lainnya sudah berada pada tinggi dan sisanya yaitu sebesar $28,18 \%$ masih berada pada tingkat rendah.

\section{Hubungan Karakteristik dengan Kapasitas Rumah Tangga}

Untuk mengetahui hubungan karakteristik rumah tangga dengan kapasitas rumah tangga di Kelurahan Bansir Darat dilakukan analisis kuantitatif asosiasi uji perbedaan ratarata menggunakan Independent Sample T Test, adapun syarat yang harus dipenuhi untuk melakukan uji perbedaan rata-rata adalah data per kelompok berdistribusi normal, data per kelompok tidak terdapat outlier, dan varians antar kelompok sama atau homogen. Hubungan karakteristik rumah tangga dengan kapasitas rumah tangga di Kelurahan Bansir Darat yang berhasi teridentifikasi adalah sebagai berikut:

\section{Hubungan Kelompok Pekerjaan dengan Kapasitas Rumah Tangga}

Berdasarkan identifikasi karakteristik rumah tangga yang menjadi responden di Kelurahan Bansir Darat terdapat 4 kelompok pekerjaan sehingga analisis kuantitatif asosiasi untuk uji perbedaan rata-rata bisa dilakukan dengan One-Way ANOVA karena terdapat lebih dari 2 kelompok, pengujian dengan One-Way ANOVA untuk mengetahui hubungan kelompok pekerjaan dengan kapasitas rumah tangga tidak dapat dilanjutkan karena pada salah satu kelompok terdapat pencilan (outliner). Untuk menghilangkan pencilan (outliner) bisa dilakukan dengan mereduksi data yang menjadi terdeteksi, namun dengan mereduksi data yang terdeteksi akan mengurangi jumlah sampel yang telah ditentukan dalam penelitian. Dalam penelitian ini cara yang dilakukan untuk menghilangkan pencilan (outliner) dilakukan dengan mereduksi jumlah kelompok pekerjaan menjadi 2 yaitu kelompok pekerjaan wiraswasta/pegawai tetap dan kelompok pekerjaan pegawai tidak tetap/tidak bekerja.

Setelah kelompok pekerjaan direduksi menjadi 2 kelompok, maka untuk mengetahui perbedaan kapasitas rumah tangga dalam menghadapi kabut asap dari kelompok pekerjaan wiraswasta dan pegawai tetap dengan kelompok pekerjaan pegawai tidak tetap dan tidak bekerja dapat dilakukan Independent Sample T Test. Hasil uji normalitas dengan SPSS didapatkan nilai signifikansi Shapiro-Wilk untuk kelompok pekerjaan wiraswasta dan pegawai tetap 0,307 dan kelompok pekerjaan pegawai tidak tetap dan tidak bekerja 0,099 dimana keduanya memiliki nilai lebih dari $0,05(>0,05)$ yang menunjukkan kedua kelompok terdistribusi dengan normal. Adapun Box-plot uji normalitas dari 2 kelompok pekerjaan dengan kapasitas rumah tangga yang menunjukkan tidak terdapat pencilan (outliner) dapat dilihat pada gambar berikut: 


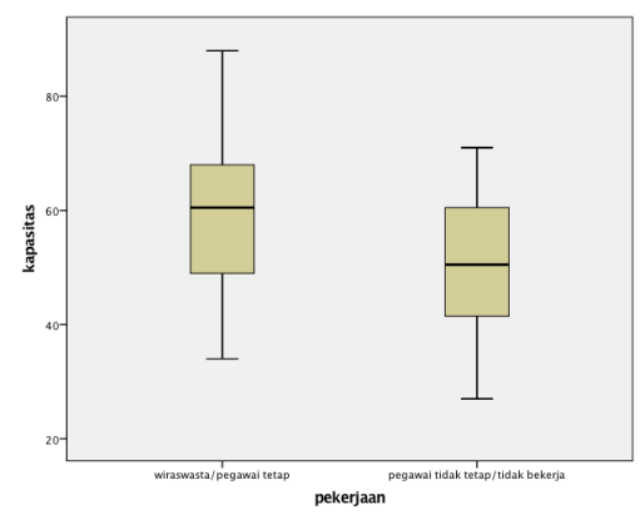

(Output SPSS, 2017)

\section{Gambar 10. Box-plotuji normalitas kapasitas rumah tangga berdasarkan kelompok pekerjaan}

Setelah syarat normalitas terpenuhi dan kedua kelompok dipastikan tidak memiliki pencilan (outliner) maka pengujian dapat dilanjutkan pada tahap selanjutnya. Berdasarkan hasil SPSS nilai Levene's Test menunjukkan angka 0,911 dimana lebih besar dari 0,05 $(0,911>0,05)$ yang berarti tidak signifikan, hal ini menunjukkan bahwa varians dalam kedua kelompok adalah sama (dengan kata lain syarat homogenitas terpenuhi). Selanjutnya untuk mengetahui hubungan kelompok pekerjaan dengan kapasitas rumah tangga dilakukan dengan melihat nilai t. Nilai t menunjukkan angka 3,400 dengan signifikansi 0,001, hal ini dapat diartikan bahwa nilai t signifikan karena nilai signifikansinya lebih kecil dari 0,05 $(0,001<0,05)$.

Karena ketiga syarat uji perbedaan rata-rata terpenuhi dan nilai t yang dihasilkan signifikan maka dapat dapat diambil kesimpulan bahwa kelompok pekerjaan memiliki pengaruh terhadap kapasitas rumah tangga. Rumah tangga dengan kelompok pekerjaan wiraswasta dan pegawai tetap memiliki rata-rata kapasitas rumah tangga yang lebih baik dalam menghadapi kabut asap dibandingkan rumah tangga dengan kelompok pekerjaan tidak tetap dan tidak bekerja, perbedaan ini dapat dilihat pada hasil SPSS yang menunjukkan perbedaan rata-rata kapasitas rumah tangga dibawah ini.

\begin{tabular}{|c|c|c|c|c|c|}
\hline \multicolumn{6}{|c|}{ Group Statistics } \\
\hline & pekerjaan & $\mathrm{N}$ & Mean & $\begin{array}{c}\text { Std. } \\
\text { Deviation }\end{array}$ & $\begin{array}{l}\text { Std. Error } \\
\text { Mean }\end{array}$ \\
\hline kapasitas & $\begin{array}{l}\text { wiraswasta/pega } \\
\text { wai tetap } \\
\text { pegawai tidak } \\
\text { tetap/tidak } \\
\text { bekerja }\end{array}$ & $\begin{array}{l}66 \\
44\end{array}$ & $\begin{array}{l}59.29 \\
50.86\end{array}$ & $\begin{array}{l}12.828 \\
12.586\end{array}$ & $\begin{array}{l}1.579 \\
1.897\end{array}$ \\
\hline
\end{tabular}

(Output SPSS, 2017)

Gambar 11. Nilai rata-rata kapasitas rumah tangga berdasarkan kelompok pekerjaan

\section{Hubungan Jenis Permukiman dengan Kapasitas Rumah Tangga}

Berdasarkan identifikasi karakteristik rumah tangga yang menjadi responden di Kelurahan Bansir Darat terdapat 2 jenis permukiman sehingga analisis kuantitatif asosiasi untuk uji perbedaan rata-rata bisa dilakukan dengan Independent Sample T Test. Hasil uji normalitas menggunakan SPSS didapatkan nilai signifikansi Shapiro-Wilk untuk perumahan 0,896 dan bukan perumahan 0,114 dimana keduanya memiliki nilai lebih dari 0,05 $(>0,05)$ 
yang menunjukkan kedua kelompok terdistribusi dengan normal. Adapun Box-plot uji normalitas dari 2 jenis permukiman dengan kapasitas rumah tangga yang menunjukkan tidak terdapat pencilan (outliner) dapat dilihat pada gambar berikut:

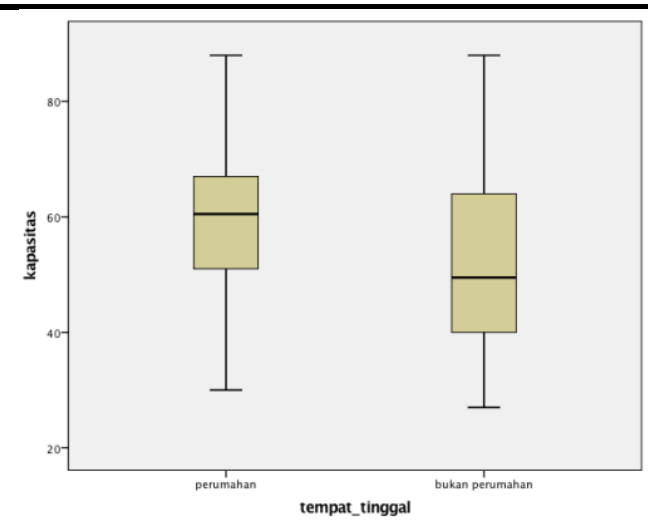

(Output SPSS, 2017)

Gambar 12. Box-plot uji normalitas kapasitas berdasarkan jenis permukiman

Setelah syarat normalitas terpenuhi dan kedua kelompok dipastikan tidak memiliki pencilan (outliner) maka pengujian dapat dilanjutkan pada tahap selanjutnya. Berdasarkan hasil SPSS nilai Levene's Test menunjukkan angka 0,067 dimana lebih besar dari 0,05 $(0,067>0,05)$ yang berarti tidak signifikan, hal ini menunjukkan bahwa varians dalam kedua kelompok adalah sama (dengan kata lain syarat homogenitas terpenuhi). Selanjutnya untuk mengetahui hubungan jenis permukiman dengan kapasitas rumah tangga dilakukan dengan melihat nilai t. Nilai t menunjukkan angka 3,167 dengan signifikansi 0,002, hal ini dapat diartikan bahwa nilai t signifikan karena nilai signifikansinya lebih kecil dari 0,05 $(0,002<0,05)$.

Karena ketiga syarat uji perbedaan rata-rata terpenuhi dan nilai t yang dihasilkan signifikan maka dapat dapat diambil kesimpulan bahwa jenis permukiman memiliki pengaruh terhadap kapasitas rumah tangga. Rumah tangga dengan jenis permukiman perumahan memiliki rata-rata kapasitas rumah tangga yang lebih baik dalam menghadapi kabut asap dibandingkan rumah tangga dengan jenis permukiman bukan perumahan, perbedaan ini dapat dilihat pada hasil SPSS yang menunjukkan perbedaan rata-rata kapasitas rumah tangga dibawah ini.

\begin{tabular}{|rl|r|r|r|c|}
\hline \multicolumn{7}{|c|}{ Group Statistics } \\
\hline & tempat_tinggal & $\mathrm{N}$ & Mean & $\begin{array}{c}\text { Std. } \\
\text { Deviation }\end{array}$ & $\begin{array}{c}\text { Std. Error } \\
\text { Mean }\end{array}$ \\
\hline kapasitas & perumahan & 60 & 59.45 & 11.684 & 1.508 \\
& bukan & 50 & 51.68 & 14.054 & 1.988 \\
\hline
\end{tabular}

(Output SPSS, 2017)

\section{Gambar 13. Nilai rata-rata kapasitas rumah tangga berdasarkan jenis permukiman}

\section{DISKUSI}

Secara umum kapasitas rumah tangga di Kelurahan Bansir Darat dalam menghadapi bencana kabut asap akibat karhutla berdasarkan kriteria yang digunakan dapat dilihat pada tabel berikut: 
Tabel 3. Tingkat kapasitas rumah tangga di Kelurahan Bansir Darat

\begin{tabular}{lllll}
\hline \multirow{2}{*}{ Kriteria } & & \multicolumn{3}{c}{ Persentase } \\
& Tinggi & Sedang & Rendah & Total \\
\hline Ekonomi & 29,09 & 40,00 & 30,91 & 100,00 \\
Pengetahuan dan Keterampilan & 10,91 & 60,91 & 28,18 & 100,00 \\
Teknologi dan Informasi & 40,00 & 40,91 & 19,09 & 100,00 \\
Infrastruktur & 29,09 & 52,73 & 18,18 & 100,00 \\
Kapasitas Rumah Tangga & 21,82 & 50,00 & 28,18 & 100,00 \\
\hline
\end{tabular}

Dari tabel hasil analisis tingkat kapasitas rumah tangga di Kelurahan Bansir Darat diatas, terlihat bahwa untuk kriteria pengetahuan dan keterampilan adalah kriteria dengan persentase tingkat tinggi terkecil dibandingkan kriteria yang lain yaitu sebesar 10,91\% sedangkan kriteria ekonomi menjadi kriteria dengan persentase tingkat rendah tertinggi yaitu sebesar 30,91\%. Secara keseluruhan kapasitas rumah tangga di Kelurahan Bansir Darat dalam menghadapi bencana kabut asap dari karhutla adalah $21,82 \%$ pada tingkat tinggi, $50,00 \%$ pada tingkat sedang dan $28,18 \%$ pada tingkat rendah. Kondisi ini dapat diartikan bahwa baru terdapat $21,82 \%$ rumah tangga di Kelurahan Bansir Darat yang siap menghadapi bencana kabut asap, 28,18\% yang tidak siap menghadapi bencana kabut asap dan $50,00 \%$ yang cukup siap menghadapi bencana kabut asap. Kapasitas rumah tangga dihitung berdasarkan kriteria yang telah ditentukan, maka rumah tangga pada tingkat sedang (cukup siap) bisa sangat tinggi dalam salah satu kriteria namun rendah di kriteria lainnya sehingga rumah tangga pada kategori ini berpotensi menjadi tidak siap ketika bencana kabut asap terjadi. Dari uraian diatas, 21,82\% rumah tangga di Kelurahan Bansir Darat siap menghadapi bencana kabut asap sedangkan $78,18 \%$ sisanya masih cukup rentan dan membutuhkan bantuan ketika bencana kabut asap terjadi.

Berdasarkan uji perbedaan rata-rata menggunakan Independent Sample $T$ Test terhadap karakteristik rumah tangga dan kapasitas rumah tangga di Kelurahan Bansir Darat teridentifikasi hubungan yang signifikan antara kelompok pekerjaan dengan kapasitas rumah tangga dan jenis permukiman dan kapasitas rumah tangga. Rumah tangga dengan kelompok pekerjaan tetap (wiraswasta dan pegawai tetap) memiliki rata-rata kapasitas rumah tangga yang lebih baik dari rumah tangga dengan kelompok pekerjaan tidak tetap (pegawai tidak tetap dan tidak bekerja), dan rumah tangga yang tinggal di permukiman berupa perumahan memiliki rata-rata kapasitas rumah tangga yang lebih baik dari rumah tangga yang tinggal di permukiman bukan perumahan atau dibangun swadaya. Dari 2 karakteristik yang memiliki pengaruh signifikan terhadap kapasitas rumah tangga di Kelurahan Bansir Darat sama-sama berhubungan dengan stabilitas penghasilan. Rumah tangga dengan penghasilan lebih stabil cenderung memilih untuk tinggal di perumahan yang berkembang pesat di Kelurahan Bansir Darat sehingga kapasitas rumah tangga dalam menghadapi bencana kabut asap di perumahan menjadi lebih baik, berbeda dengan rumah tangga di permukiman bukan perumahan (rumah kampung) dimana kesenjangan penghasilan akan lebih tinggi yang berpengaruh pada rendahnya kapasitas rumah tangga dalam menghadapi bencana kabut asap.

Kajian mengenai bencana karhutla banyak membahas mengenai akar permasalahan, dampak yang ditimbulkan, valuasi kerugian dan kajian kebijakan baik dalam mengurangi maupun menanggulangi karhutla, adapun penelitian ini mencoba untuk melengkapi kajian yang sudah ada dan difokuskan kepada kabut asap yang ditimbulkan oleh karhutla. Kriteria yang digunakan dalam kapasitas rumah tangga pada penelitian ini banyak disintesakan dari kapasitas adaptif rumah tangga dalam menghadapi perubahan iklim, hal ini dilakukan karena bencana kabut asap terjadi secara perlahan-lahan (slow on set) dan dapat diprediksikan kejadiannya sehingga memiliki sifat yang mirip dengan beberapa bencana yang diakibatkan perubahan iklim. 
Upaya pengurangan risiko bencana dapat dilakukan dengan menurunkan ancaman dan kerentanan dan meningkatkan kapasitas, dalam Perka BNPB 2/2012 kapasitas diartikan sebagai kemampuan daerah dan masyarakat untuk melakukan tindakan pengurangan tingkat ancaman dan tingkat kerugian akibat bencana. Kajian kapasitas rumah tangga dalam penelitian mencoba memberikan gambaran mengenai kondisi rumah tangga dalam menghadapi bencana khususnya kabut asap, hasil dari kajian ini diharapkan dapat menjadi masukkan bagi pemerintah baik pusat maupun daerah dalam mengantisipasi bencana kabut asap yang diakibatkan karhutla.

\section{KESIMPULAN}

Dari uraian diatas dapat disimpulkan bahwa kriteria yang dapat digunakan untuk mengukur kapasitas rumah tangga dalam menghadapi bencana kabut asap akibat karhutla adalah : ekonomi, pengetahuan dan keterampilan, teknologi dan informasi, dan infrastruktur. Berdasarkan 4 kriteria yang digunakan, hasil perhitungan terhadap kapasitas rumah tangga di Kelurahan Bansir Darat menunjukkan bahwa 21,82\% siap, 28,18\% tidak siap dan 50,00\% cukup siap menghadapi bencana kabut asap. Dengan menggunakan 4 kriteria, maka rumah tangga dalam kategori cukup siap bisa sangat tinggi di satu kriteria namun rendah di kriteria lainnya atau sebaliknya, sehingga bisa disimpulkan bahwa baru $21,82 \%$ rumah tangga yang siap, sedangkan sebesar $78,18 \%(28,18 \%+50,00 \%)$ rumah tangga sisanya masih membutuhkan bantuan ketika bencana kabut asap terjadi.

Dari 2 karakteristik rumah tangga yang teridentifikasi memiliki pengaruh terhadap kapasitas rumah tangga adalah kelompok pekerjaan dan jenis permukiman dimana rumah tangga dengan kelompok pekerjaan wiraswasta dan pegawai tetap memiliki rata-rata kapasitas rumah tangga yang lebih baik dibandingkan rumah tangga dengan kelompok pekerjaan tidak tetap dan tidak bekerja, dan rumah tangga dengan jenis permukiman perumahan memiliki rata-rata kapasitas rumah tangga yang lebih baik dibandingkan rumah tangga dengan jenis permukiman bukan perumahan, hal ini mengindikasikan bahwa penghasilan rumah tangga yang cukup stabil membentuk kapasitas rumah tangga yang lebih baik dalam menghadapi bencana kabut asap akibat karhutla.

Saran yang dapat diberikan kepada instansi pemerintah, untuk meningkatkan kapasitas rumah tangga di Kelurahan Bansir Darat dalam menghadapi bencana kabut asap akibat karhutla adalah dengan memprioritaskan kriteria kapasitas rumah tangga yang berada pada kategori Tinggi dengan prosentase kecil, maupun kriteria pada kategori Rendah dengan prosentase besar yaitu kriteria Ekonomi dan kriteria Pengetahuan dan Keterampilan (secara rinci dapat dilihat pada Tabel 3.). Selain itu, upaya meningkatkan kapasitas rumah tangga dapat mempertimbangkan kelompok pekerjaan dan jernis permukiman di Kelurahan Bansir Darat yang terbukti secara signifikan memiliki pengaruh terhadap kapasitas rumah tangga dalam menghadapi bencana kabut asap. Secara umum prioritas untuk meningkatkan kapasitas rumah tangga dalam menghadapi bencana kabut asap akibat karhutla di Kelurahan Bansir Darat adalah meningkatkan kriteria Ekonomi dan kriteria Pengetahuan dan Keterampilan, sedangkan pertimbangan selanjutnya adalah rumah tangga dengan pekerjaan tidak tetap/tidak bekerja dan tinggal di permukiman bukan perumahan.

\section{DAFTAR PUSTAKA}

Hansford, B. (2011). Reducing risk of disaster in our communities. Tearfund.

Heil, A., \& Goldammer, J. G. (2001). Smoke-haze pollution: a review of the 1997 episode in Southeast Asia. Regional Environmental Change, 2(1), 24-37. https://doi.org/10.1007/s101130100021

Hendon, H. H. (2003). Indonesian rainfall variability: Impacts of ENSO and local air-sea interaction. Journal of Climate, 16(11), 1775-1790.

KMNLH RI. (1998). Kebakaran Hutan Dan Lahan Di Indonesia : Dampak, Faktor Dan Evaluasi (No. 1). Jakarta: Kantor Menteri Negara Lingkungan Hidup Republik Indonesia. 
Liu, J. C., Pereira, G., Uhl, S. A., Bravo, M. A., \& Bell, M. L. (2015). A systematic review of the physical health impacts from non-occupational exposure to wildfire smoke. Environmental Research, 136, 120-132. https://doi.org/10.1016/j.envres.2014.10.015

Logan, J. A., Megretskaia, I., Nassar, R., Murray, L. T., Zhang, L., Bowman, K. W., ... Luo, M. (2008). Effects of the 2006 El Niño on tropospheric composition as revealed by data from the Tropospheric Emission Spectrometer (TES). Geophysical Research Letters, 35(3). https://doi.org/10.1029/2007GL031698

Penalba, L. M., \& Elazegui, D. D. (2011). Adaptive capacity of households, community organizations and institutions for extreme climate events in the Philippines. Singapore: EEPSEA.

Purnomo, H., Okarda, B., Shantiko, B., Achdiawan, R., Kartodihardjo, H., \& Dewayani, A. A. (2015). Asap penggunaan lahan dan politik lokal. Conference Paper.

Purnomo, H., Shantiko, B., Sitorus, S., Gunawan, H., Achdiawan, R., Kartodihardjo, H., \& Dewayani, A. A. (2017). Fire economy and actor network of forest and land fires in Indonesia. Forest Policy and Economics, 78, 21-31. https://doi.org/10.1016/j.forpol.2017.01.001

Ross, A. (2013). Local Disaster Resilience across the Gulf Coast: Intersecting Capacities for and Perceptions of Resilience. Routledge.

Smit, B., \& Pilifosova, O. (2003). Adaptation to Climate Change in The Context of Sustainable Development and Equity. Sustainable Development, 8(9), 9.

Statheropoulos, M., \& Karma, S. (2007). Complexity and origin of the smoke components as measured near the flame-front of a real forest fire incident: A case study. Journal of Analytical and Applied Pyrolysis, 78(2), 430-437. https://doi.org/10.1016/j.jaap.2006.10.011

Stockwell, C. E., Jayarathne, T., Cochrane, M. A., Ryan, K. C., Putra, E. I., Saharjo, B. H., .. Yokelson, R. J. (2016). Field measurements of trace gases and aerosols emitted by peat fires in Central Kalimantan, Indonesia, during the 2015 El Niño. Atmospheric Chemistry and Physics, 16(18), 11711-11732. https://doi.org/10.5194/acp-16-11711-2016

Swanson, D., Hiley, J., Venema, H. D., \& Grosshans, R. (2007). Indicators of Adaptive Capacity to Climate Change for Agriculture in the Prairie Region of Canada: An analysis based on Statistics Canada's Census of Agriculture. Working Paper for the Prairie Climate Resilience Project, Winnipeg: International Institute for Sustainable Development.

Syaufina, L. (2008). Kebakaran Hutan dan Lahan di Indonesia : Perilaku Api, Penyebab, dan Dampak Kebakaran (I). Malang: Bayumedia Publishing.

Tacconi, L. (2003). Kebakaran hutan di Indonesia: penyebab, biaya dan implikasi kebijakan. CIFOR, Bogor, Indonesia. Diambil dari http://www.cifor.org/publications/pdf_files/OccPapers/OP-038i.pdf

Tangang, F., Latif, M. T., \& Juneng, L. (2010). The roles of climate variability and climate change on smoke haze occurrences in Southeast Asia region.

Wall, E., \& Marzall, K. (2006). Adaptive Capacity for Climate Change in Canadian Rural Communities. Local Environment, 11(4), 373-397. 